\author{
Dominika Łarionow \\ Department of Art History, University of Łódź \\ larionow@gazeta.pl
}

\title{
TADEUSZ KANTOR - ENGAGEMENT - MULTIPLICATION - PARTICIPATION
}

\begin{abstract}
The article discusses the Multipart project prepared by Tadeusz Kantor for the Foksal Gallery in Warsaw (1970 and 1971). The name's neologism arose from the combination of words: multiplication and participation. The author's intention was formulated in the manifesto accompanying the whole event. For Kantor, it was important to question the notion of a work of art against growing consumerism. The artist was the author of a project of 40 canvases, which were used for umbrellas. The performers of the whole were students of the Academy of Fine Arts in Warsaw. The works were sold at the vernissage to start the second part of the Multipart. The spectators' participation was secured with a carefully written contract and assumed that the final shape of the work would be created through and through the recipient's creativity.

From today's historical perspective, thanks to the works of Claire Bishop, it is quite easy to see the ideas of the artist of Polish convergence with the ideas of the Situationalist International. Kantor, with all the fascination with the possibility of active involvement of the viewer in the creation of the work, did not associate his actions with politics or any aspect of politics. This fact clearly separates his way of thinking about the function of art in the modern world from the leftist movement of situationists.
\end{abstract}

Keywords: Tadeusz Kantor, Polish art in XX century, The Situationist International, Guy Debord, The Foksal Galery in Warsaw.

In 1970 Tadeusz Kantor prepared an action for the Foksal Gallery in Warsaw with the seemingly incomprehensible title: Multipart. The neologism was coined by combining two words: multiplication and participation. Today it is difficult to say whether the aforementioned concepts were an intentional reference to the theory of the Situationist International, founded in the late 1950s in Paris, more than a decade earlier. Undoubtedly, in a more detailed analysis of Kantor's work we will find as many convergences as the opposite points. 
Situationists were a social and artistic movement that brought together various intellectuals from France, Italy, Denmark and the Netherlands. The principal theoretician was Guy Debord, whose book Society of the Spectacle, even though published in 1967, was considered one of the ideological foundations of the student revolt of 1968. Debord criticized both the capitalist society, which was developing towards consumerism, and the socialist statehood, which was drowning in bureaucracy. He understood the very structures of societies as a great space for constantly staged performances at different levels of state organization. Debord's theories were based on ideas previously signaled in the writings of Karl Marx, but also by György Lukács. Although Situationists are mainly identified with the social movement, they also had an impact on the art of that era. The artists associated with Debord were particularly interested in the achievements of the avant-garde of the early twentieth century, Dadaists and Surrealists in particular. They did not so much duplicate the gestures of preceding artists as they updated them, giving them meaning in the spirit of the new philosophy.

Writing about the participatory art of the 1960s, Claire Bishop noted that in 1957, when the Letterist International was replaced by the Situationist International, the idea of "constructed situation" became the guiding motto. The concept was defined by the founders of the movement as "a moment of life, concretely and deliberately constructed by the collective organisation of a unitary ambiance and a game of events". ${ }^{1}$ Bishop concluded that its participatory structure was an important feature of the new concept. It emerged from the opposition to the traditional artist-recipient relations, in which the latter was estranged, alienated, passive towards the act of "happening" of art. The proposed new relationship was associated with the communal character of creation, albeit one that had a profound political sense in the suggested interpretation. Bishop clarified the issue:

Collectively realised 'constructed situations' were figured as oppositional to capitalism in their sublation of individual authorship, but primarily in their refusal of bureaucracy and consumerism through the free activity of the game. ${ }^{2}$

In Multipart's action, Kantor seems to have thought along the same lines as he created a work of which he was not the author in the full scope of

1 Unsigned, 'Definitions', in Internationale Situationniste, 1, 1958, p. 13, in: Claire Bishop, Artificial hells. Participatory Art and the Politics of Spectatorship, Verso, London-New York, 2012, p. 87.

2 Bishop, p. 86. 
the concept. At the same time, the annual participation he planned became a game between the artist and the recipients of art. The final effect became the subject of the next exposition. The arranged project had two parts, both of which took place at the Foksal Gallery in Warsaw: one on 21 February 1970 and the other on 20 February 1971. During the first one, forty copies of one painting were exhibited in the rather small-sized gallery. The composition itself was multiplied and all the duplicated works were 110 by $120 \mathrm{~cm}$ in size. First an umbrella was sewn onto each canvas, and then the whole thing was painted white. Kantor was the author of the project, and the required items came from the Bureau of Found Things. The whole thing was described in detail, including all technical data. Students of the Academy of Fine Arts in Warsaw, who were the main contractors of Multipart, realized of the project.

The opening of the first part of Kantor's project was accompanied by the sale of paintings. Those willing to purchase works had to sign a detailed contract, which imposed a number of obligations on them. The most important was to hang the painting in one's own house in a prominent place and to make it available to all visitors. At the same time, everyone would be given an unrestricted access to the canvas in order to write or draw whatever they wanted. The fourth point of the contract clearly defined the position of the owner in relation to the painting, considering that the owner should have "a clear ambition to do something outstanding." 3 A person who owns the work of art "can, if he or she wishes, by persuasion, choice and other methods applied to the co-creators, leave the mark of his or her individuality". ${ }^{4}$ The author, however, undertook to provide all information whenever the owner felt the need for such consultation. The freedom which the artist gave left to the buyer also included the possibility of making radical changes in the structure of the work, which could be cut or expanded by adding new parts to it.

The paintings were purchased by art critics, Polish and foreign artists and private persons. ${ }^{5}$ As in any agreement, there is also a catch in this one. After six months, the owner was obliged to return the canvas to the author in order to re-expose it. Before the deadline, Kantor sent the buyers a letter reminding them that the work had to be returned. Unfortunately, not all the paintings

3 Tadeusz Kantor z Archiwum Galerii Foksal, ed. Joanna Mytkowska, Małgorzata Jurkiewicz, Andrzej Przywara, Fundacja Galerii Foksal, Warszawa 1998, p. 202.

4 Ibid., p. 202.

5 The full list of names of all the owners of the paintings was published in the book Tadeusz Kantor z Archiwum Galerii Foksal. These included art critics and curators such as Anna Ptaszkowska, Ryszard Stanisławski or Marek Rostworowski, but also artists such as Grzegorz Moryciński, Erna Rosenstein, Janina Ścieszko, students from the Zuzanna and Spółka group, as well as Annette and Theodore Ahrenberg from Switzerland, Walter Baran from New York, Achille Perilla from Rome, Andreas Wall from Stockholm etc. 
came back. Eventually, at the second Multipart exhibition, which took place in 1971 and became known as the "collectors' vernissage", only - or as many as thirty-four of the forty works were shown. However, Kantor was not interested in the number of returned canvases, but in the reception of the works and the willingness of the viewers to take up the initiated game. The artist wrote about it quite clearly in Multipart's Manifesto dating back to 1969:

The author is not interested in the aspect of popularization and extensive publicity concerning the multiplas. Rather, he sees them as a personal opportunity to go beyond the limits of aesthetic fact. In fact, the author is basically against the multiplas, although he does not deny their existence, he wants to bring them back to the starting point; without losing anything from their usual action, he wants to leave a special and unique mark on them, through participation. Participation of other people. ${ }^{6}$

Kantor was right because participation construed as co-creation became the most inspiring part of Multipart. Many of the paintings displayed in 1971 now contain notes, some full of delight, such as statements: "good - probably the beginning of a new era in art", but there was a lot of mockery, too: "This Tadeusz Kantor has probably just been released from the looney bin". Some inscriptions on the concerned prosaic information, e.g. "soon Karolinka or Michał will be born" or " I love Maciek" or "I love you Ann", as well as slogans have appeared: "Those who talk back live shorter". Various photographs and objects, such as a key or a tiny plush teddy bear were glued to the paintings. The Warsaw artistic formation called the Second Group repainted the whole painting in gold, then cut it in half, thus establishing the line of the golden division.

Marek Rostworowski, art historian and museum employee, left the purchased canvas intact. In order to meet the stipulation of returning the painting to the gallery, he appealed to Kantor to produce one more copy numbered 41, which he could receive in exchange for the one he was returning. This longstanding curator of the Princes Czartoryski Museum in Krakow justified his request as a potential curator who is interested in the work as an artifact. At the same time, Rostworowski also treated the option of owning a painting permanently as a peculiar document confirming his participation as an art historian in Kantor's action. However his discourse was contrary to Kantor's principles. Recognizing participation as the most important element of the action, the artist wrote in the Multipart Manifesto:

6 Tadeusz Kantor z Archiwum Galerii Foksal, p. 211. 
The author transfers numerous prerogatives of the so-called creativity to other people, who are not deprived of the hope and appearances of possessing a work of art. ${ }^{7}$

Thus, one could say that Kantor' point was to challenge the very notion of a work of art. More specifically, to show the world that today there is no longer such thing as an author, understood as a charismatic figure at the forefront of a school, an epoch or a style. Twentieth century saw the emergence of a community or collectivization, as we would say using the language of Situationists with Marxist background. Wiesław Borowski, co-founder of Galeria Foksal, had similar feelings. He commented on Multipart with regard to the play with the concept of authorship of a work of art challenged by Kantor. The art critic drew attention to similar issues as Rostworowski, concluding that the latter's appeal was intended to adapt Kantor's acts to the requirements of the art collectors to date. Borowski, however, as an art historian, was opposed to traditional forms of understanding of periodization or systematization introduced in relation to artistic output in museums at that time.

"The Manifestation with Multipart," Borowski wrote, "is at the same time a new encounter between painting and mental reality, marked by the participation of other ready-made people, unknown, from outside of the realm of art. The final effect of this procedure is also a ready-made object, which was incorporated into painting rather than being one". 8

This new purpose of art made its artifacts, on the one hand, always open works of art, while on the other, they were to exist only as objects, museum items animated only by the participation of the audience. This reification that concerned even participation as a fact was an important part of Kantor's legacy. He made the act of objectification his own artistic strategy. ${ }^{9}$ In her analysis of the Situationist movement, Claire Bishop also pointed to the tendency towards the reification of art objects, which the artists associated with Debord traced back to the era of the great avant-garde of the first half of the century, albeit giving them not so much artistic but more ideological meaning. The researcher cites the example of postcards, which were important for Surrealists. Artists headed by André Breton attacked the social culture of the nineteenth century by altering bourgeois postcards and giving them erotic undertones. ${ }^{10}$ In the second half of the twentieth century on turn, slogans added to the well-

\footnotetext{
7 Ibid., pp. 211-212.

8 W. Borowski, Kantor. Ambalaże i multipart, "Współczesność" 1970, nr 28.

9 More on the subject In my book: „Wystarczy tylko otworzyć drzwi...” Przedmioty w twórczości Tadeusz Kantora, Wydawnictwo Uniwersytetu Łódzkiego, Łódź 2015.

10 Cf Agnieszka Taborska, Spiskowcy wyobraźni, Stowo/obraz terytoria, Gdańsk 2007.
} 
known images of pin-up girls were a bit more in tune with the spirit of Marxism: "The emancipation of the workers will be their own goal" or "There is nothing better than sleeping with a miner from Asturias. He is one hunk of a real man!" Describing these examples, Bishop also considers them to be an excellent demonstration of the use of the détournement strategy, which was important for Situationists. Debord introduced this concept by referring directly to Dadaists and Surrealists. The researcher notes that "a good détournement reversed the ideological function of the effluvia of spectacle culture, but without adopting the form of a simple inversion of the original, since this would keep the latter's identity securely in its place." ${ }^{11}$ This is surely what the Surrealist artists did. Debord rather meant "the subversive appropriation of existing images to undermine their existing meaning." ${ }^{2}$ Therefore, by questioning the original sense, it was possible to use a given thing as a sign of new content conferred by an ideological action rather than a spontaneous creative act.

Kantor was partly seduced by the détournement strategy, which is evident, for example, in the ten-meter high chair-monument designed for Wrocław in 1970, which was completed at the same time as Multipart. Clearly, the very idea of placing such sculptures in public spaces was to be reversed. For the artist, this great utility object was excluded from all utilitarian functions, as well as from all ideological ones, which distinguishes Kantor's work from the actions of French artistic and social activists. The concrete seat was not supposed to serve anyone, it did not represent a leader on horseback, nor did it refer to the victories of any army. It was supposed to be only a support for wind and rain. One could say that in Multipart, as well as in the Wrocław project, Kantor was only interested in the consumption of meaning. Detournement concerned the manipulation on the basic meaning of the object chosen by the artist, in this case a chair was turned into a monument. In 1970 at the Foksal Gallery, a potential work of art with a value determined by the author's name and rank was transformed into a multiplied composition of a painting that had several unnamed authors. Kantor was afraid that such a profaned work would not find a buyer. This time he was wrong, because the multipart became a valuable object for the commodity exchange system. A more precise example is the history of a participation that did not result in the return of the work to the gallery. On February 16, 1971, Kantor received a letter from Janusz Skalski, buyer of one of the forty paintings:

Your painting, according to the terms of the contract (i.e. that part thereof that stipulates what can be done with the work) has been sold by

11 Bishop, p. 84.

12 Ibid. 
me to a Finnish citizen, Jorma Pitkonen, residing in Helsinki, 17 Mariankatu $13 \mathrm{bH} 36$. I estimated the value of the painting at $\$ 10$, which the abovementioned Finn paid. For this money I have purchased men's trousers called jeans in the PKO shop on Czackiego Street. [....] Of course, prior to concluding the sale, I had acquainted myself with the terms of the contract, unfortunately, despite several requests sent to Helsinki in order to persuade Mr Jorma Pitkonene to return the work to the exhibition, I have not received an reply. ${ }^{13}$

From today's perspective, Skalski's letter is an excellent document of the era. After all, not many people remember the time when the so-called luxury goods, i.e. goods from capitalist countries and thus the jeans mentioned above, were available only in special establishments. The successor of PKO shops were PEWEKS ${ }^{14}$ outlets, popular until the end of the communist era. Therefore, the purchase of valuable trousers for even more valuable dollars was an exceptional exchange of goods, saying a lot about the value of a multiplied work of art at that time. However, this story seems to correspond exactly to what Kantor wanted to achieve. In the aforementioned Manifesto, he noticed that the work of art was threatened by becoming commercialized. "The author does not deny the possibility of creating a work of art with values that elude commerciality. The author is not sure, however, whether in today's consumer society there can still be something for which a greedy buyer will not be found." 15

The story of Jorma Pitkonene, a Finnish artist, was a proof that a potential buyer was found, although certainly from his perspective the sum of $\$ 10$ was not as high as it was from Skalski's point of view. However, the story, in which jeans were put on one side of the scales, and a work of art on the other reflected a certain goal that Kantor included in his Manifesto:

To create the appearances of commerciality, to blow them up, to bloat them into colossal fiction and a fascinating illusion, and to such an extent that when its proper sense is completely lost from sight and the work ceases to be a commodity, the author does not intend to define what it becomes. ${ }^{16}$

13 Cited In: Tadeusz Kantor z Archiwum..., p. 45.

14 PEWEX stands for Internal Export Company. It was a state-owned enterprise established in 1972 as a result of transformation of foreign exchange shops of the PKO bank. Pewexes were state stores in which the so-called convertible currencies, i.e. American dollars and vouchers available in limited quantities could be used to buy goods unavailable in other stores. Prices of the products were not subject to any customs duty.

15 Tadeusz Kantor z Archiwum Galerii Foksal, op. cit, p. 213.

16 Ibid., p. 213. 
Kantor's concluding words may be considered prophetic. Participation became a success, the aspect of which not only was noticeable in 1971, but also had its vicissitudes of unexpected consequences. It was not just Pitkonene who was even fascinated by a white umbrella sewn onto an equally white canvas. Students from Warsaw universities established a formation in 1970: Zuzanna i Spótka [Susanna and the Company], composed of: Zuzanna Trojanowska from the Music Academy and: Krzysztof Ozimiek, Stanisław Lichota, Krzysztof Sroczyński, Marek Młodecki, Krzysztof Kubicki, Leszek Kordowicz from the Faculty of Architecture of the Warsaw University of Technology. Witold Krassowski, professor of architecture, became the chairman of the self-proclaimed group. For the sum of 500 PLN, the group bought a painting at the Foksal Gallery in order to make it a subject of several artistic activities.

The first fully documented creative gesture made by the student company was to attach a stick and colored ribbons to the multipla so it resembled the so-called "feretron", that is portable religious paintings carried by the faithful on the Roman-Catholic feast of Corpus Christi during processions. Thusly ornamented painting was carried by the students during an official parade which took place in Warsaw on the occasion of the state holiday on May 1, 1970. It can be said that the members of the group made a détournement, the subject of which was the multipla from Kantor's actions. It is important to mention here some essential facts needed to understand the intentions of Susanna and the Company. Labor Day parades on May 1 were a special event in the culture of the communist state. On the one hand, they were used by the authorities to demonstrate strength and consolidate their power, and on the other hand, they were in fact forced rallies of workers brought specially from factories, hospitals, schools, etc. People were required to participate in the rituals of power. It should also be remembered that the country was apparently ideologically separated from religion and all forms of sacred worship. Thus, a work of art carried like an altar in front of the grandstand where state officials stood and gave fiery speeches was mainly a kind of bold mockery at that time. Undoubtedly, the students' actions served to break down the artificial seriousness of the whole May 1 situation. The gestures of the young participants were somewhat dangerous, as they were clearly mocking the authorities and could therefore face serious repressions. Fortunately, this did not happen, although the whole action of Susanna and the Company was registered by the cameraman filming the parade for the Polish Film Chronicle.

After the successful May action, the students did not know how to share the expensive painting. They decided to sow cress on it and give such a naturally distorted work to Wiesław Borowski as the head of the Foksal Gallery. Unfortunately, the busy art critic forgot to water the artistic plant and decided to give the work back to the buyers. The participants of the Zuzanna and the 
Company group accepted the work, but this time they decided to bury it in the gardens of the former Zamoyski family palace on Foksal Street in Warsaw. The building housed the Association of Polish Architects SARP. Students approached the preparations professionally: using toilet paper, they marked a long "white" line from the central axis of the building, then took 44 steps and started digging. The hole in the ground was more or less in the middle of the garden. The whole complicated action of burying the multipla was recorded on film by Młodecki and Kubicki. Both of them were members of a film club operating at the student club "Stodoła" and had access to film cameras, which was uncommon at the time.

This story has a peculiar epilogue. In May 2012, i.e. forty-one years later, members of the Susanna and the Company group invited the audience to take part in the performance of digging out the multipla. A glass pavilion was erected in the garden of the Zamoyski Palace, archaeologists were summoned and the digging started. To the surprise of all gathered, the painting was indeed recovered. The excavated object has retained its shape, but the work required complex restoration. Susanna and the Company collected money for the renovation through social networking sites. ${ }^{17}$

Certainly, Kantor, who died in 1990, did not expect that the participation initiated in 1970 would last more than forty years. This is probably the greatest success of art, the aim of which was to persuade the viewer to co-participate. Analyzing participatory movements, Bishop attaches great importance to their political character. The two-part Multipart did not have such an ideological premise. At that time, the artist avoided unambiguous manifestations of views. Although in Kantor's art we will find many works whose metaphors clearly comment on the oppressive situation of a totalitarian state, the artist approached the political discourse with finesse. This issue has not yet been well discussed by researchers. It is undisputable that Multipart, carried out at the Foksal Gallery in 1970 and 1971, was an important activity of the Polish artist, performed in the spirit of the Situationist art.

\section{BIBLIOGRAPHY}

Bartoszewicz Dariusz (18 May 2012) Odkopali dzieło Kantora po 40 latach. Zachowato się, "Gazeta Wyborcza”.

17 Cf. D. Bartoszewicz, "Widać zarys parasola" wykopali Kantora po 40 latach, "Gazeta Wyborcza”, 21 May 2012; Cf. also, idem:, Odkopali dzieło Kantora po 40 latach. Zachowato się, "Gazeta Wyborcza" 18 May 2012. 
Bartoszewicz Dariusz, (21 May 2012) "Widać zarys parasola" wykopali Kantora po 40 latach, "Gazeta Wyborcza".

Bishop Claire (2012) Artificial hells. Participatory Art and the Politics of Spectatorship, Verso, London-New York.

Borowski Wiesław (1970), Kantor. Ambalaże i multipart, "Współczesność" nr 28.

Łarionow Dominika (2015) „Wystarczy tylko otworzyć drzwi...” Przedmioty w twórczości Tadeusz Kantora, Wydawnictwo Uniwersytetu Łódzkiego, Łódź.

Mytkowska Joanna, Jurkiewicz Małgorzata, Przywara Andrzej ed. (1998) Tadeusz Kantor z Archiwum Galerii Foksal, Fundacja Galerii Foksal, Warszawa.

Taborska Agnieszka (2007), Spiskowcy wyobraźni, Stowo/obraz terytoria, Gdańsk.

\section{TADEUSZ KANTOR - ZAANGAŻOWANIE - MULTIPLIKACJA - PARTYCYPACJA (streszczenie)}

Artykuł omawia akcję Multipart przygotowaną przez Tadeusza Kantora dla Galerii Foksal w Warszawie (1970 i 1971). Neologizm nazwy powstał z połączenia słów: multiplikacja i partycypacja. Intencja autora została sformułowana w towarzyszącym całemu wydarzeniu manifeście. Dla Kantora było ważne zakwestionowanie pojęcia dzieła sztuki wobec narastającego wokół konsumpcjonizmu. Artysta był autorem projektu 40 płócien, do których doszyto parasole. Wykonawcami całości byli studenci Akademii Sztuk Pięknych w Warszawie. Prace zostały sprzedane na wernisażu by rozpoczać drugą część Multipartu. Partycypacja widzów została obwarowana dokładnie spisaną umową i zakładała, że ostateczny kształt dzieła powstanie poprzez i dzięki kreatywności odbiorcy.

Z dzisiejszej perspektywy historycznej, dzięki opracowaniom Claire Bishop dość łatwo można się dopatrzeć w pomysłach Kantor zbieżności z ideami Międzynarodówki Sytuacjonistycznej. Kantor, przy całej fascynacji możliwością aktywnego zaangażowania widza w kreację dzieła, swojego działania nie wiązał z polityką czy jakimkolwiek aspektem polityczności. Fakt ten wyraźnie oddziela jego sposób myślenia o funkcji sztuki we współczesnym świecie od zbudowanego na korzeniach lewicowych ruchu sytuacjonistów.

Słowa kluczowe: Tadeusz Kantor, sztuka polska XX wieku, Międzynarodówka Sytuacjonistów, Guy Debord, Galeria Foksal 